\title{
Vegetative anatomy of three potted Chrysanthemum varieties under various paclobutrazol concentrations
}

\author{
INTANI QUARTA LAILATY ${ }^{1,2, \boldsymbol{v}}$, LAURENTIUS HARTANTO NUGROHO ${ }^{2, \bullet v}$ \\ ${ }^{1}$ Cibodas Botanic Gardens, Research Center for Plant Conservation and Botanic Gardens, Indonesian Institute of Sciences. Jl. Kebun Raya Cibodas, \\ Sindanglaya, Cipanas, Cianjur 43253, West Java, Indonesia Tel./fax.: +62-263-512233, vemail: intani.quarta.lailaty@lipi.go.id \\ ${ }^{2}$ Department of Tropical Biology, Faculty of Biology, Universitas Gadjah Mada. Jl. Teknika Selatan, Sekip Utara, Sleman 55281, Yogyakarta, Indonesia. \\ Tel./fax.:+62-274-580-839.••mail: hartantonugroho2005@ugm.ac.id
}

Manuscript received: 26 November 2020. Revision accepted: 7 January 2021

\begin{abstract}
Lailaty IQ, Nugroho LH. 2021. Vegetative anatomy of three potted Chrysanthemum varieties under various paclobutrazol concentrations. Biodiversitas 22: 563-570. Chrysanthemum is one ornamental plant with high potential to be developed commercially. It has many varieties such as colors, types, and shapes of flowers. Paclobutrazol (PBZ) is one of plant growth regulators used to suppress plant growth. The PBZ action mechanism is to inhibit gibberellin synthesis. The application of PBZ with a certain concentration on Chrysanthemum plants has the potential to form potted Chrysanthemum. The aim of this study was to analyze the anatomical variation of potted mums varieties, i.e. Jaguar Red, Snow White and Fiji White, and also the effect of PBZ with various concentrations on the anatomy of the stems and leaves of three Chrysanthemum varieties. The research was conducted by applying PBZ concentrations of 0 , $50,100,150 \mathrm{ppm}$ to the three Chrysanthemum varieties and grown for 8 weeks to form potted Mums. Then, the anatomy of stems and leaves was studied using the paraffin and freehand section methods. Data analysis was performed using ANOVA and DMRT (Duncan Multiple Range Test) for anatomical characters in stems and leaves of three Chrysanthemum varieties. The results showed that the length of the epidermal cells of Fiji white variety was longer than those of Snow White and Jaguar Red. Meanwhile, Jaguar Red produced greater stem thickness, stomata, and leaf thickness than those of the other two varieties. PBZ could increase the size of the anatomical parameters of Chrysanthemum stems and leaves for all varieties. The PBZ concentration of 150 ppm increased leaf thickness and stem diameter, as well as tracheal diameter. The PBZ concentration of $100 \mathrm{ppm}$ increased the size of the guard cells, palisade and spongy tissue, also peripheral tissues. Meanwhile, the PBZ concentration of $50 \mathrm{ppm}$ had an effect on the increase in the number of stomata and pith diameter. The optimum PBZ concentration to form potted Chrysanthemum was $150 \mathrm{ppm}$.
\end{abstract}

Keywords: Anatomy, Chrysanthemum, growth retardant, ornamental plant, paclobutrazol

\section{INTRODUCTION}

Chrysanthemum is an ornamental plant with high economic value and potential to be developed commercially. In Indonesia, the mums is widely cultivated in the medium and highlands. Yogyakarta is one of the centers for Chrysanthemum cultivation in Indonesia with the rapidly increasing demand for cut flowers (Puspitasari and Indradewa 2019). Chrysanthemum is in great demand by the public because it has a variety of colors, types, and shapes of flowers compared to other flowers. The mum flowers are also classified as not easy to wither. It has shape of a crown, beautiful colors, and reasonable prices, so it dominates most of the flower industries in Southeast Asia and European countries (Banerji and Datta 2002). Chrysanthemum varieties are very numerous and variable, including Jaguar, Fiji, Snow, Shena, Anastasia, Yoko Ono, Sakuntala, and others. Besides being used as cut flowers, it can also function as potted ornamental plants.

Nowadays, consumers tend to prefer potted flowers that are not too tall with stalks and internodes, have lush leaves, and have uniform and compact flowers. The potted flowers are formed according to market tastes, it is necessary to have special treatment. It can be through by the application of plant growth regulators. One of them is by using paclobutrazol. Paclobutrazol (PBZ) is a growth regulator that is often used to suppress plant growth (Soumya et al. 2017). PBZ application with different concentrations in several plants produced various growth results. Paclobutrazol induced leaf, stem, and root anatomical modification in potato and potted Geranium (Tsegaw et al. 2005; Abd El-Aal and Mohamed 2017). Growth and anatomical responses in Xanthostemon chrysanthus and Syzygium campanulatum were influenced by paclobutrazol (Nazarudin et al. 2015; Nazarudin et al. 2007). Rubiyanti and Rochayat (2015) also reported that paclobutrazol concentration and time of PBZ application had affect on batik Rose growths.

This growth inhibitor works as an anti-gibberellin which functions in the elongation of stems, nodes of stem, evapotranspiration also affects the wet weight and dry weight of the leaves. PBZ inhibits gibberellin biosynthesis. It will make reduction in the length of internodes caused by inhibition of cell enlargement. In addition, stem shortening is also caused by inhibition of cell division and elongation of the sub-apical meristem, as a result, internode extension is inhibited (Nazarudin et al. 2012; Francescangeli et al. 2007; Mansuroglu et al. 2009). PBZ is effective in suppressing the growth of stem height, so the potted plants can be formed (Faust et al. 2001; Gibson and Whipker 2001). 
Tsegaw et al. (2005) reported that leaves of potato plants showed an increased epicuticular wax layer thickness, elongated and thicker epidermal, palisade, and spongy mesophylls cells. It induced of thicker cortex, larger vascular bundles, and wider pith diameter associated with larger pith cells. In Xanthostemon chrysanthus (F. Muell.) Benth, xylem thickness in the stem was reduced after treated with the highest dosage of paclobutrazol, palisade parenchyma was found the thickest after PBZ treatment (Nazarudin et al. 2015). Meanwhile, based on Burrows et al. (1992), PBZ treatment in this stems from increased development of secondary xylem and a reduced number of sclerenchyma bundle caps in Chrysanthemum morifolium. Therefore, the aim of this study was to compare the anatomy of stems and leaves of three varieties of Chrysanthemum, i.e. Jaguar Red, Fiji White, and Snow White, based on the results of plant growth with the application of PBZ.

\section{MATERIALS AND METHODS}

\section{Planting Chrysanthemums and application of PBZ}

Chrysanthemum varieties, i.e. Jaguar Red, Snow White, and Fiji White were obtained from Puspita Merapi Farm, Yogyakarta, Indonesia. The three Chrysanthemum varieties were planted in polybags, with 5 replications per each variety. Plants were maintained until 2 weeks after planting. Then the application of paclobutrazol by spraying on the stems and leaves of the Chrysanthemums was conducted. Each variety was treated with PBZ in the concentration of 50,100 and $150 \mathrm{ppm}$, and distilled water as a control. PBZ was applied once a week for 3 times. Plants are maintained well until the age of 7 weeks and the appearance of flower buds.

\section{Anatomical preparation of Chrysanthemum stems and leaves}

Stem and leaf used were 8 weeks old plants. The leaf was the $5^{\text {th }}$ leaf from shoot, while the stem was the internode part of the stem.

\section{Cross-section of leaves and stems by embedding method}

Cross-sections of leaf and stem were prepared using the paraffin method (Ruzin 1999). The stem and leaf were collected and put in a flacon bottle containing $70 \%$ alcohol. The samples were fixed with FAA (formaldehyde - acetic acide - alcohol) solution for $24 \mathrm{~h}$. After the fixation, washing and dehydration were carried out. Dehydration was processed using a series of alcohol solutions (70\%, $80 \%$, 95\%, and 100\%), $30 \mathrm{~min}$. for each step. Dealcoholized was processed by passing through graded series of alcohol: xylene solutions (3: 1, 1: 1, 1: 3) up to $100 \%$ xylene (twice), $30 \mathrm{~min}$. for each step. The tissues were embedded into a mixture of xylol: paraffin (1: 9) and put down on thermostat $57{ }^{\circ} \mathrm{C}$ for $24 \mathrm{~h}$. Infiltration was carried out by replacing the mixture of xylol/paraffin from the tissues with pure paraffin and stored in a thermostat at a temperature of $57{ }^{\circ} \mathrm{C}$ for $24 \mathrm{~h}$. The following steps were removing pure paraffin and replacing the paraffin with new one for about 1 hour, then making a block in a Petri dish smeared with $15 \%$ glycerin. The paraffin-embedded tissues were sectioned at the thickness of $20 \mu \mathrm{m}$ using rotary microtome. The section tapes were then placed on the objective glass smeared with $15 \%$ glycerin followed by placing the objective glass on a low-temperature hot plate $\left(45{ }^{\circ} \mathrm{C}\right)$ until the paraffin tape stretches. The tissues were then stained by inserting a glass objective into a series of staining jars consecutively containing pure xylol, the mixture of alcohol and xylol with the composition of 3: 1, 1: 1, 1: 3, alcohol 100\% 2 times, $95 \%, 80 \%, 70 \%$ for 3 min. each, followed by staining with $1 \%$ safranin in $70 \%$ alcohol for 5-8 hours. The following process was removing excess stain by inserting the objective glass in a series of staining jars consecutively containing graded concentrations of alcohol. The concentration were $70 \%$, $80 \%, 95 \%, 100 \%, 100 \%$ for 1 minute each. The objective glass was then put in the mixture of alcohol and xylol in the ratio 3: 1, 1: 1, 1: 3, then finally the pure xylol solution. The sections were then mounted in Canada balsam and dried on hot plate at $45{ }^{\circ} \mathrm{C}$. The anatomical examination was done using light microscope at the magnification of $10 \times 40$, and captured using OptiLab microscope camera. The parameters examined in the stem cross-section were the stem diameters, the ratio of peripheral and pith tissue, the size of pith cells, and the size of the tracheal cells while the parameters of leaf cross-section examination were the thickness of the leaves, the ratio of palisade and sponge tissue thickness in the mesophyll.

\section{Cross-section of leaves and stems by freehand section}

Preparation of longitudinal slices of stems and leaves were prepared using the freehand section method according to Ruzin (1999). The stem and leaf samples were collected and put in a flacon bottle containing $70 \%$ alcohol. The epidermal peels of leaf lower surfaces and stem were made manually. The median area of the leaves was placed on a clean glass slide. Then the epidermis of the desired surface was peeled-off carefully with sharp razor blade. The epidermal peels were stained in $1 \%$ aqueous solution of safranin overnight, rinsed carefully in water to remove excess stain, and then mounted in $10 \%$ glycerol. The epidermal structure of stems and leaves was examined under a light microscope. Four slides replicate were done at the magnification of $10 \times 40$, and captured using OptiLab microscope camera. The length of the epidermal cells was observed in the stem longitudinal section, while the number of stomata per unit area, as well as the length and width of the stomata guard cells, were observed in the leaf longitudinal sections.

\section{Data analysis}

The qualitative data of stem and leaf anatomy were analyzed descriptively while quantitative data were analyzed using analysis of variance (ANOVA) with the F test at 5\% significance level by MS. Excel and SPSS ver.16. If the $\mathrm{F}$ test has a significant effect, an intermediate test with the Duncan Multiple Range Test (DMRT) was performed at a $5 \%$ significance level. 


\section{RESULTS AND DISCUSSION}

\section{Stem anatomy on three varieties of Chrysanthemum}

Jaguar Red produced greater stem thickness, based on thickness of cortex area and thickness of pith tissue, than those of other two varieties. The trachea diameter of Jaguar Red was also bigger than those of Snow White and Fiji White. Meanwhile, the length of the epidermal cells of Fiji White variety was longer than those of Snow White and Jaguar Red (Table 1). The results were in accordance with the morphology of Fiji White which is higher than those of Jaguar Red and Snow White.

Chrysanthemum belongs to Dicotyledonae which commonly has 3 parts of anatomical stem structure namely epidermis, cortex, and stele. From Figure 2 and Figure 3, it can be seen trichomes and stomata as Chrysanthemum stem epidermal derivatives. Stomata facilitated an air exchange from inside and outside cell. Stem trichome serves protection and reduces evaporation. From this study, the type of trichome on the Chrysanthemum stem was nonglandular trichomes. This is in accordance with research from Dalaila et al. (2019).

Based on the results, paclobutrazol inhibited the elongation of stem epidermal cells at three varieties of Chrysanthemum. The higher concentration of PBZ given demonstrated the greater inhibition of cell elongation. From the statistical test, it was known that there was a significant difference between control and PBZ treatment on the length of epidermal cells. Overall, $150 \mathrm{ppm}$ of PBZ was the most effective in inhibiting the length of stem epidermal cell (Table 1). It was characterized by a shorter length of epidermal cells than those of the control (Figure 1).

PBZ activity inhibits gibberellin, especially affect the reduction of plant stem elongation. The reduction in internode length due to the inhibition of cell enlargement (Tsegaw et al. 2005). This inhibition of epidermal cell elongation affects the growth and morphology of
Chrysanthemum stems. The higher PBZ concentration resulted in slower stem growth. According to Soumya et al. (2017), PBZ inhibits the oxidative reaction between kauren and kaurenoic acid in gibberellin synthesis, so there was an emphasis on plant stems. Apart from inhibition of cell enlargement, the shortening of the stem was also caused by the inhibition of cell division and elongation of the subapical meristem. Therefore, PBZ treatment caused shortening of the stem epidermal cells which was also could be indicated by the inhibition of stem height in the three Chrysanthemum varieties.

In this study, the stem used was 8 weeks old which already showed secondary growth indicated by the vascular bundles which were attached to a loop of the vascular tissues (Figures 2 and 3). Chrysanthemum has open collateral of vascular type, with the eustele of stele type. From Table 1, it is known that the stems were getting thick after PBZ application proved by an increase in the size of the stem diameters. The higher concentration of PBZ increased wide stem diameter compared to those of the lower concentration. Stem of Jaguar Red was thickest than those of other varieties. Meanwhile, Snow White showed the smallest stem diameter. Based on statistical analyses, it is known that the application of PBZ has an effect on the increase of diameter stem at the three varieties of Chrysanthemum. The concentration of $150 \mathrm{ppm}$ was significantly different from the control.

The cortical tissue of Chrysanthemum stem composed of parenchyma cells that contain chlorophyll functioning in photosynthesis. The mentioned cells are called chlorenchyma. The outer edge cortex consisted of collenchyma or sclerenchyma. The boundary between the cortex and the vascular tissue was unclear because due to the lack of endodermis cells. The stele consisted of vascular tissue and pith. The pith was located at the center of the stem (Figure 3).

Table 1. The anatomical quantitative variation of the stem of three Chrysanthemum varieties

\begin{tabular}{|c|c|c|c|c|c|c|}
\hline Varieties & PBZ & $\mathrm{EC}(\mu \mathrm{m})$ & $\mathrm{CT}(\mu \mathrm{m})$ & PT $(\mu \mathrm{m})$ & $\mathrm{PC}(\mu \mathrm{m})$ & $\mathrm{TC}(\mu \mathrm{m})$ \\
\hline Jaguar Red & $\begin{array}{l}\text { Control } \\
50 \% \\
100 \% \\
150 \% \\
\text { Mean }\end{array}$ & $\begin{array}{l}100.03^{\mathrm{c}} \\
80.39^{\mathrm{b}} \\
68.68^{\mathrm{b}} \\
35.93^{\mathrm{a}} \\
71.26\end{array}$ & $\begin{array}{l}318.60^{\mathrm{d}} \\
261.76^{\mathrm{cd}} \\
428.72^{\mathrm{e}} \\
108.74^{\mathrm{a}} \\
279.46\end{array}$ & $\begin{array}{l}4563.72^{\mathrm{b}} \\
1550.28^{\mathrm{a}} \\
1019.44^{\mathrm{a}} \\
1065.30^{\mathrm{a}} \\
2049.69\end{array}$ & $\begin{array}{l}129.42^{\text {cde }} \\
120.02^{\text {bcde }} \\
104.36^{\text {abcd }} \\
87.18^{\mathrm{a}} \\
110.25\end{array}$ & $\begin{array}{l}45.46^{\mathrm{b}} \\
29.06^{\mathrm{a}} \\
24.42^{\mathrm{a}} \\
30.56^{\mathrm{a}} \\
32.38\end{array}$ \\
\hline Snow White & $\begin{array}{l}\text { Control } \\
50 \% \\
100 \% \\
150 \% \\
\text { Mean }\end{array}$ & $\begin{array}{l}100.605^{\mathrm{e}} \\
69.79^{\mathrm{b}} \\
65.19^{\mathrm{b}} \\
65.52^{\mathrm{b}} \\
75.28\end{array}$ & $\begin{array}{l}132.58^{\mathrm{a}} \\
233.62^{\mathrm{bc}} \\
273.32^{\mathrm{cd}} \\
173.00^{\mathrm{ab}} \\
203.13\end{array}$ & $\begin{array}{l}1316.16^{\mathrm{a}} \\
1362.30^{\mathrm{a}} \\
870.34^{\mathrm{a}} \\
796.02^{\mathrm{a}} \\
1086.21\end{array}$ & $\begin{array}{l}132.56^{\text {de }} \\
128.26^{\text {cde }} \\
109.54^{\text {abcde }} \\
93.34^{\text {ab }} \\
115.93\end{array}$ & $\begin{array}{l}27.64^{\mathrm{a}} \\
39.60^{\mathrm{a}} \\
25.08^{\mathrm{a}} \\
30.42^{\mathrm{a}} \\
30.69\end{array}$ \\
\hline Fiji White & $\begin{array}{l}\text { Control } \\
50 \% \\
100 \% \\
150 \% \\
\text { Mean }\end{array}$ & $\begin{array}{l}100.36^{\mathrm{d}} \\
100.07^{\mathrm{c}} \\
68.07^{\mathrm{b}} \\
56.69^{\mathrm{ab}} \\
81.30\end{array}$ & $\begin{array}{l}101.26^{\mathrm{a}} \\
96.30^{\mathrm{a}} \\
145.34^{\mathrm{a}} \\
145.90^{\mathrm{a}} \\
122.20\end{array}$ & $\begin{array}{l}1053.76^{\mathrm{a}} \\
1310.22^{\mathrm{a}} \\
1431.54^{\mathrm{a}} \\
1392.46^{\mathrm{a}} \\
1297.00\end{array}$ & $\begin{array}{l}135.88^{c} \\
126.10^{\text {cde }} \\
112.68^{\text {abcde }} \\
101.88^{\text {abc }} \\
119.14\end{array}$ & $\begin{array}{l}24.94^{\mathrm{a}} \\
23.76^{\mathrm{a}} \\
31.30^{\mathrm{a}} \\
40.34^{\mathrm{b}} \\
30.09\end{array}$ \\
\hline
\end{tabular}

Note: n: 3, PBZ (PBZ concentrations), EC (length of epidermis cells), CT (thickness of cortex area), PT (thickness of pith tissue), PC (diameter of pith cells), TC (diameter of trachea cells) 


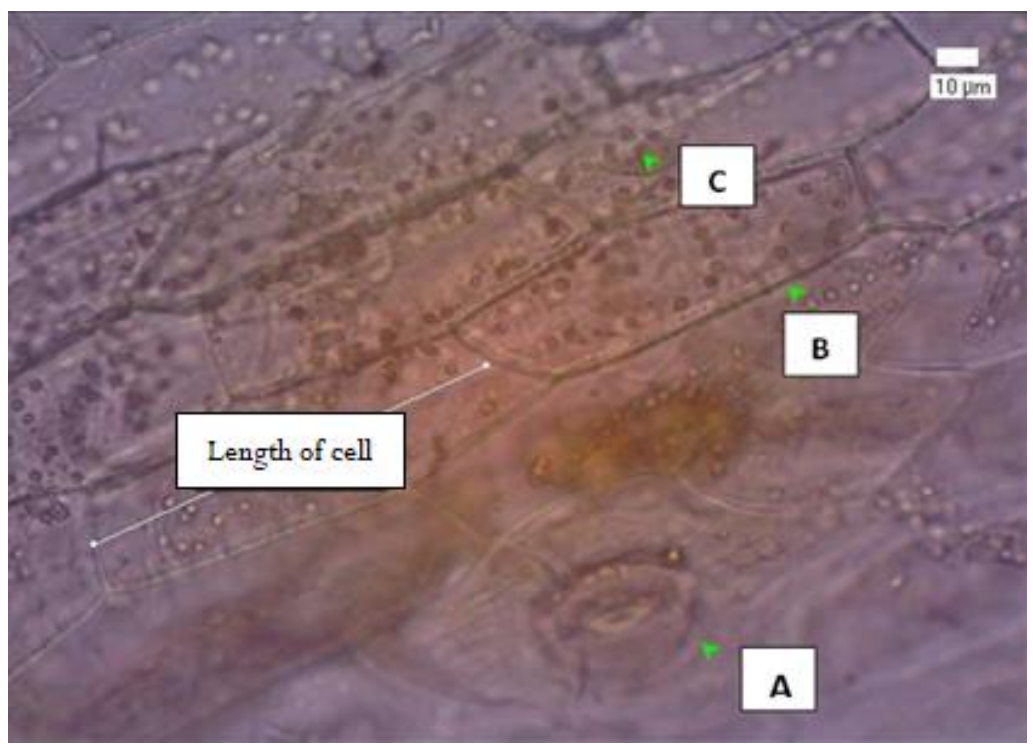

Figure 1. Cross-section of Chrysanthemums stem. A. Stomata, B. Cell wall, C. Chloroplast

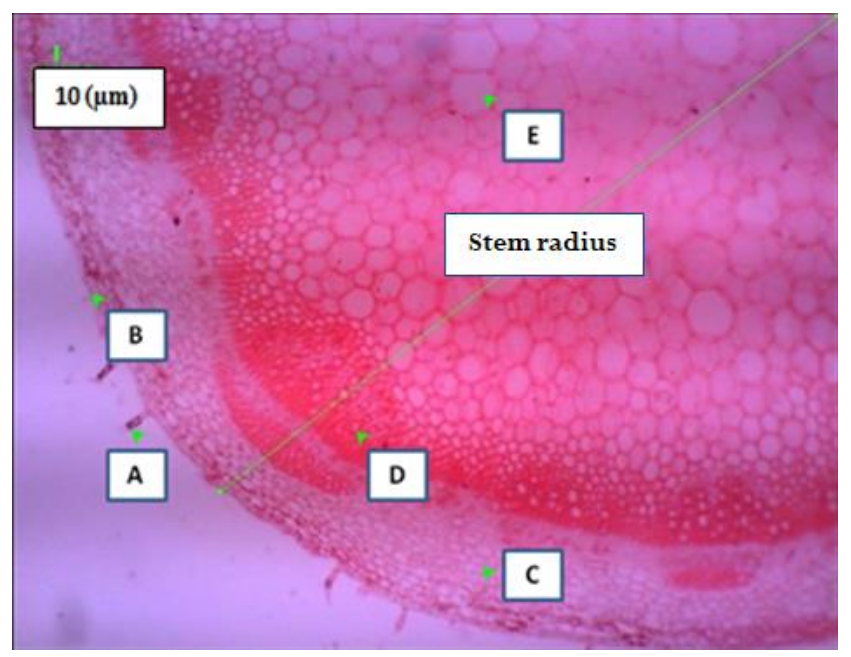

Figure 2. Cross-section of Chrysanthemums stem. A. Trichome, B. Epidermis, C. Cortex, D. Vascular bundle, E. Pith

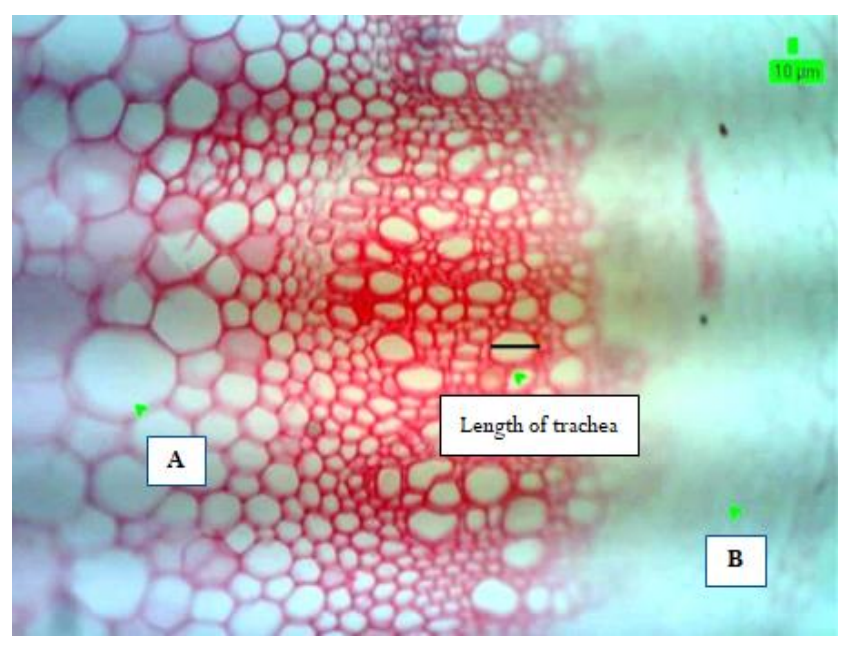

Figure 4. Trachea cell cross-section of Chrysanthemums stem. A. Pith, B. Cortex

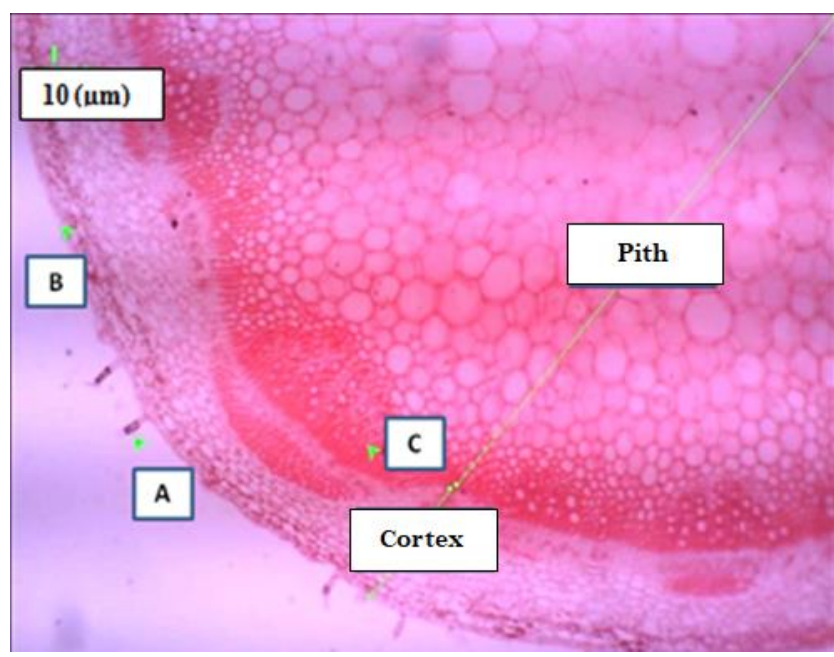

Figure 3. Cross-section of Chrysanthemums stem. A. Trichome, B. Epidermis, C. Vascular bundle

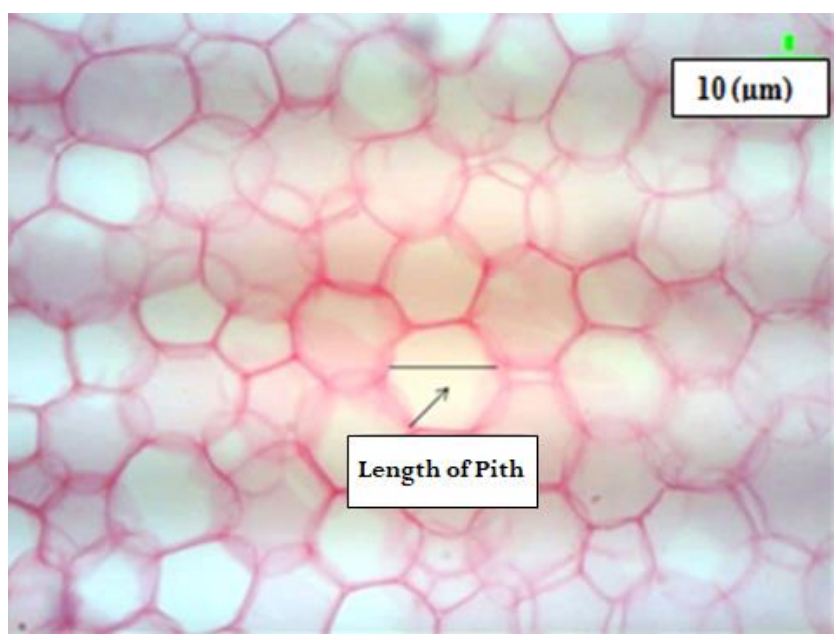

Figure 5. Cell piths cross-section of Chrysanthemums stem 
The cortical tissue of Chrysanthemum stem composed of parenchyma cells that contain chlorophyll functioning in photosynthesis. The mentioned cells are called chlorenchyma. The outer edge cortex consisted of collenchyma or sclerenchyma. The boundary between the cortex and the vascular tissue was unclear because due to the lack of endodermis cells. The stele consisted of vascular tissue and pith. The pith was located at the center of the stem (Figure 3).

Based on Table 1, all of PBZ treatments increased the thickness of stem cortex tissue in Snow White and Fiji White Chrysanthemum varieties while the concentration of PBZ 100 ppm increased the thickness of the cortex tissue in Jaguar Red variety, However, the concentrations of 50 and $150 \mathrm{ppm}$ treatments were not able to increase the thickness of the cortex tissue in Jaguar Red variety. This current condition was indicated by the thicker cortical tissue in the control treatment compared to those of the 50 and $150 \mathrm{ppm}$ PBZ treatments. The thickness of the cortical tissue could be due to the activity of paclobutrazol which increases the cortical parenchyma cells division resulted in the thickness of cortical tissues (Tsegaw et al. 2005). Moreover, the thickness of the cortical tissue could also be due to the size of the cortex cells that were getting bigger with the addition of PBZ. The concentration of $100 \mathrm{ppm}$ was the most optimum in increasing the thickness of the cortical tissue, while the concentration of $150 \mathrm{ppm}$ decreased the thickness of the cortex tissue. The concentration of $150 \mathrm{ppm}$ could not increase the thickness of the cortex tissue. However, the stem diameter was increasing. The current conditions may be due to the increase of the vascular bundle size such as the enlargement of tracheal cells diameter (Table 1). The xylem and phloem elements were getting bigger and bigger resulting in the increases in stem diameter(Figure 4).
The thickness of the pith tissue in the Fiji White variety increased with PBZ treatment. However, the application of PBZ actually decreased the thickness of the pith tissue in Jaguar Red and Snow White. The current condition may be due to the cortex area of Fiji White was wider than the pith area. Fiji White pith cells did not have much cell division. Therefore, the thickness of the pith tissue in Fiji White was lower than those of the other two varieties. In general, PBZ affected the thickness of the cortex and pith tissue. PBZ increased cortical tissue thickness in 100 ppm treatment as indicated the optimum concentration. However, PBZ decreased the thickness of pith tissue in Jaguar Red and Snow White varieties (Table 1).

Tsegaw et al. (2005) reported that PBZ treatment increased cortex thickness, size of the vascular bundles, and pith diameter resulted in thicker stems. The modification may be attributed to radial expansion of cells due to the reduction of endogenous Gibberellin (GA) activities in response to the treatments. Furthermore, according to Wenzel et al. (2000), GA limits the extent of radial expansion of plant organs. In dicot stems, cell shape alterations are apparently caused by a longitudinal orientation of cellulose microfibrils deposited in the cell walls. It could be preventing the parallel expansion to the microfibrils but allowing perpendicular expansion to them.

\section{Leaf anatomy in three varieties of Chrysanthemum}

The current study showed that Jaguar Red produced greater number of stomata and leaf thickness than those of the other two varieties. Jaguar Red also has thicker palisade and spongy tissue than those of the others. However, Fiji White showed a greater of length and width of guard cells compared to those of Snow White and Jaguar Red (Table 2).

Table 2. Quantitative variation on five anatomical characters of leaves on three Chrysanthemum varieties

\begin{tabular}{|c|c|c|c|c|c|c|c|}
\hline Varieties & PBZ & SN & SL $(\mu \mathrm{m})$ & $\mathrm{SW}(\mu \mathrm{m})$ & LT $(\mu \mathrm{m})$ & PT $(\mu \mathrm{m})$ & $\mathrm{ST}(\boldsymbol{\mu m})$ \\
\hline Jaguar Red & $\begin{array}{l}\text { Control } \\
50 \% \\
100 \% \\
150 \% \\
\text { Mean }\end{array}$ & $\begin{array}{l}52.75^{\mathrm{f}} \\
46.50^{\text {ef }} \\
42.25^{\text {de }} \\
37.50^{\text {bcd }} \\
44.75\end{array}$ & $\begin{array}{l}42.10^{\mathrm{ab}} \\
41.10^{\mathrm{ab}} \\
39.88^{\mathrm{ab}} \\
37.68^{\mathrm{a}} \\
40.19\end{array}$ & $\begin{array}{l}26.35^{\mathrm{Bc}} \\
23.60^{\mathrm{abc}} \\
25.80^{\mathrm{bc}} \\
24.35^{\mathrm{abc}} \\
25.03\end{array}$ & $\begin{array}{l}403.85^{\mathrm{c}} \\
484.13^{\mathrm{dc}} \\
507.73^{\mathrm{e}} \\
507.90^{\mathrm{e}} \\
475.90\end{array}$ & $\begin{array}{l}82.83^{\mathrm{a}} \\
119.10^{\mathrm{c}} \\
126.85^{\mathrm{c}} \\
124.60^{\mathrm{c}} \\
113.35\end{array}$ & $\begin{array}{l}201.70^{\text {ef }} \\
229.98^{\text {fg }} \\
252.68^{\mathrm{g}} \\
196.70^{\mathrm{def}} \\
220.27\end{array}$ \\
\hline Snow White & $\begin{array}{l}\text { Control } \\
50 \% \\
100 \% \\
150 \% \\
\text { Mean }\end{array}$ & $\begin{array}{l}45.00^{\mathrm{c}} \\
42.25^{\mathrm{de}} \\
36.50^{\mathrm{abcd}} \\
33.75^{\text {abc }} \\
39.38\end{array}$ & $\begin{array}{l}42.93^{\mathrm{ab}} \\
44.28^{\mathrm{b}} \\
42.15^{\mathrm{ab}} \\
40.30^{\mathrm{ab}} \\
42.42\end{array}$ & $\begin{array}{l}21.50^{\mathrm{a}} \\
22.30^{\mathrm{ab}} \\
24.90^{\mathrm{abc}} \\
24.05^{\mathrm{abc}} \\
23.19\end{array}$ & $\begin{array}{l}291.38^{\mathrm{a}} \\
308.65^{\mathrm{a}} \\
385.83^{\mathrm{bc}} \\
408.97^{\mathrm{c}} \\
348.71\end{array}$ & $\begin{array}{l}85.53^{\mathrm{a}} \\
82.85^{\mathrm{a}} \\
119.65^{\mathrm{c}} \\
91.10^{\mathrm{ab}} \\
94.78\end{array}$ & $\begin{array}{l}129.60^{\mathrm{a}} \\
154.15^{\mathrm{abc}} \\
192.50^{\mathrm{cdef}} \\
151.83^{\mathrm{ab}} \\
157.02\end{array}$ \\
\hline Fiji White & $\begin{array}{l}\text { Control } \\
50 \% \\
100 \% \\
150 \% \\
\text { Mean }\end{array}$ & $\begin{array}{l}29.50^{\mathrm{a}} \\
40^{\mathrm{cde}} \\
32.5^{\mathrm{ab}} \\
30.5^{\mathrm{ab}} \\
33.13\end{array}$ & $\begin{array}{l}42.48^{\mathrm{ab}} \\
43.98^{\mathrm{b}} \\
41.60^{\mathrm{ab}} \\
44.45^{\mathrm{b}} \\
43.13\end{array}$ & $\begin{array}{l}22.74^{\mathrm{ab}} \\
25.95^{\mathrm{bc}} \\
23.18^{\mathrm{abc}} \\
26.95^{\mathrm{c}} \\
24.71\end{array}$ & $\begin{array}{l}322.38^{\mathrm{ab}} \\
408.48^{\mathrm{c}} \\
427.18^{\mathrm{cd}} \\
451.30^{\mathrm{cde}} \\
402.34\end{array}$ & $\begin{array}{l}80.48^{\mathrm{a}} \\
123.40^{\mathrm{c}} \\
113.60^{\mathrm{bc}} \\
113.00^{\mathrm{bc}} \\
107.62^{2}\end{array}$ & $\begin{array}{l}157.98^{\mathrm{abc}} \\
180.23^{\mathrm{bcde}} \\
213.68^{\mathrm{ef}} \\
40.34^{\mathrm{b}} \\
148.06\end{array}$ \\
\hline
\end{tabular}

Note: n: 4, PBZ: concentration of PBZ, SN: Number of stomata, SL: Length of guard cells , SW: Width of guard cells, LT: Thickness of leaves, PT: Thickness of palisade tissue, ST: Thickness of spongy tissue 
The stomata distribution in the Chrysanthemum leaf epidermis was irregular considering that Chrysanthemum is dicot. The stomata type was amphistomatic since it can be found on the top (abaxial) and bottom (abaxial) surfaces of the leaves. However, the number of stomata found on the abaxial leaf surface was more than those of the adaxial leaf surface in all varieties of Chrysanthemum (Figure 6). The stomata number was also higher on the abaxial side compared to those of the adaxial side of the leaf blades of Chrysanthemum varieties 'Kraski Oseni', Quartet' and 'Tango' (Brailko et al. 2018). Apart from stomata, there were epidermal derivatives in the form of non-glandular trichomes.

Leaf epidermis plays a crucial role in plant-pathogen interactions (Fuchs et al. 2015). Leaf characteristics, such as the quantity and quality of the wax and cuticle, the size, location, and shape of the stomata and lenticels, and the presence of thick cell walls, may avoid pathogen infection (Araujo et al. 2014; Wang et al. 2020). Previous studies demonstrated that trichomes and cuticular wax layer acted as a protective barrier against pathogen attacking (Ferdinand et al. 2000; Javelle et al. 2011; Xu et al. 2011; Wang et al. 2020). Meanwhile, stomata played an active role in bacterial invasion (Melotto et al. 2008).

The number of stomata varies in the same plant and also in the same area. The results showed that PBZ reduced the number of stomata per unit area of leaves. The higher concentration of PBZ reduced stomata number in all treatments. In general, the Jaguar Red variety had a higher number of stomata per unit area compared to those of the other two varieties. Based on statistical tests, it is known that PBZ had an effect in reducing the number of stomata per unit area (Table 2). Since stomata function as "leaf mouths" which receive light in the process of photosynthesis, the fewer stomata inhibited photosynthesis process. Moreover, stomata also play a role in transpiration and tissue gas exchange (Haryanti 2010).

Chrysanthemum stomata type is phanerophores where the guard cells have the same surface position as leaf epidermal cells. Chrysanthemum also has anisocytic stomata type where the guard cell is surrounded by three accessory cells that are not equal (Figure 7). According to Table 2, PBZ affected the length and width of the guard cells. Overall PBZ increased the length and width of stomata guard cells. The larger pores of guard cell increase photosynthesis and transpiration processes resulted in optimal light and $\mathrm{CO}_{2}$ absorption as $\mathrm{CO}_{2}$ is the main carbon in photosynthesis.

The measurement of guard cell length showed that PBZ increased the length of guard cells, except those of Jaguar Red variety due to the number of stomata per unit area in Jaguar Red was higher compared to those of the two other varieties resulted in the size of guard cells. The optimum concentrations for guard cell elongation were PBZ $50 \mathrm{ppm}$ $150 \mathrm{ppm}$ for Snow White and Fiji White respectively (Table 2). Moreover, PBZ treatment increased the width of the guard cells in three Chrysanthemum varieties. The 100 ppm concentration of PBZ was the most optimum in increasing the width of the guard cells (Table 2). The size of this guard cell was quite variable. The results may be due to the difference in the opening time of the stomata pores resulted in the difference of cell width.

The leaf thickness showed that PBZ increased leaf thickness for the three varieties. The optimum concentration for the increase of leaf thickness was 150 ppm. Jaguar Red had the highest leaf thickness followed by Fiji White and Snow White was the lowest leaf thickness (Table 2). The thickness of mesophyll tissue increases the rate of photosynthesis due to the high quantity of chlorophyll. The results are consistent to Burrows et al. (1992) which reported that the increase of Chrysanthemum leaf thickness in response to PBZ treatment was due to induction of additional layers of palisade parenchyma. Although the individual cells were shorter and smaller diameter than those of control plants, the cells were more tightly packed.

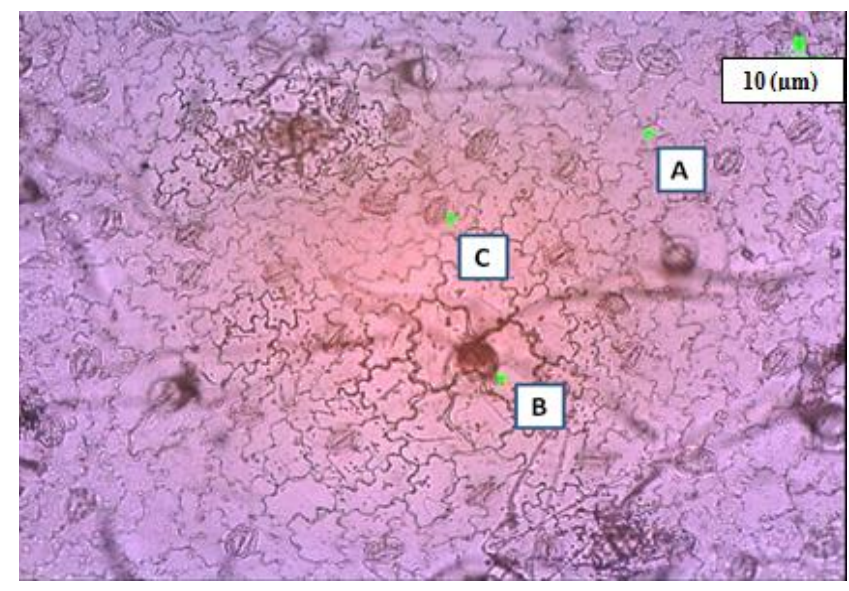

Figure 6. Cross-section of Chrysanthemum sp. leaves. A. Epidermis, B. Trichome, C. Stomata

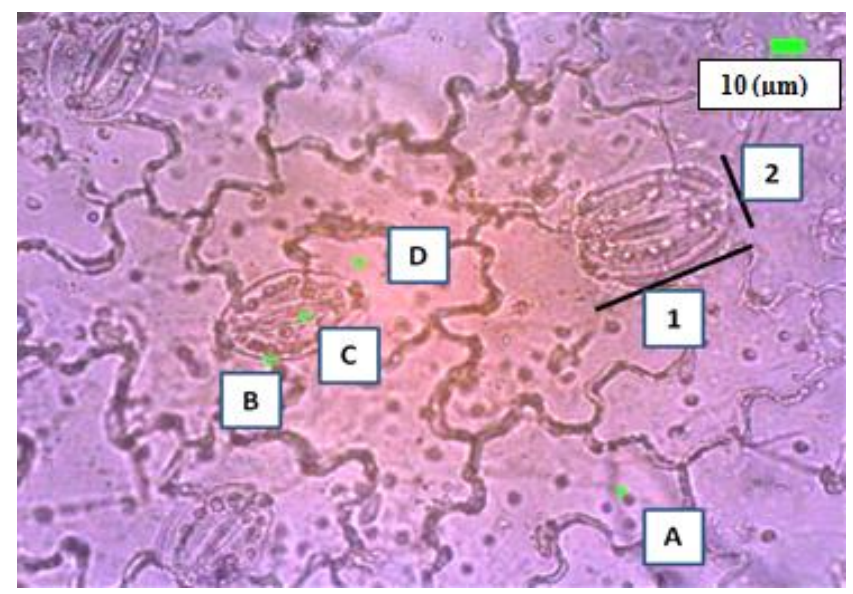

Figure 7. Cross-section of Chrysanthemum sp. leaves. A. Accessory cells, B. Guard cells, C. Porus, D. Guard cell. 1. Length of guard cell, 2. Width of guard cell 


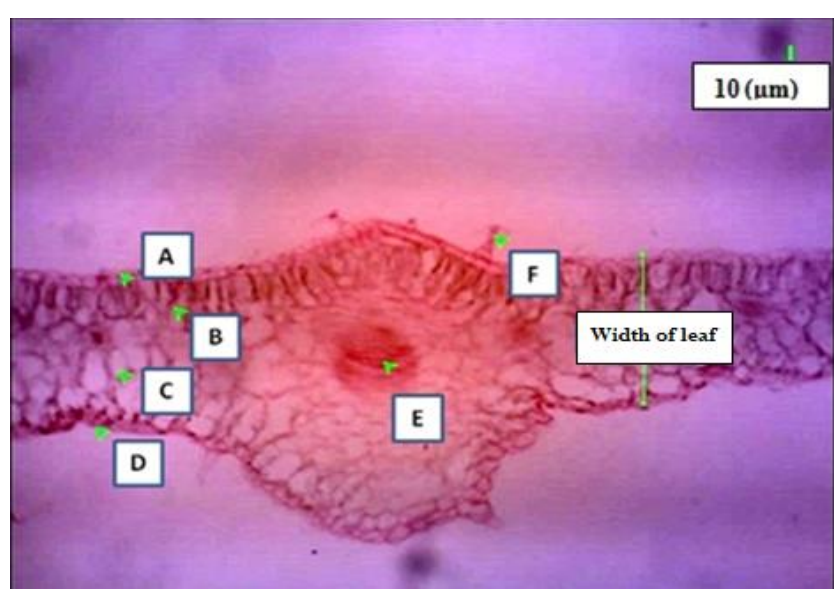

Figure 8. Cross-section of Chrysanthemum sp. leaves. A. Upper epidermis, B. Palisade tissue, C. Spongy tissue, D. Lower epidermis, (E) Vascular bundle, and (F) Trichome

Based on Table 2, it is known that PBZ application had an effect in increasing the thickness of palisade and spongy tissues in the leaves of the three Chrysanthemum varieties. The optimum concentration of PBZ in increasing palisade and sponge tissue thickness was 100 ppm. The Jaguar Red variety was the thickest spongy tissue compared to those of the other two varieties. PBZ increased palisade tissue thickness as indicated by the presence of 2-3 layers of palisade tissue in Chrysanthemum leaves (Figure 9). This is in accordance with Tsegaw (2005) who reported that PBZ increased the length and width of palisade mesophyll cells of tomato leaves by $32.6 \%$ and $41.6 \%$ respectively.

The results also showed that PBZ modified the morphology of three Chrysanthemum varieties. The plants to be dark green, short, and compact. The changes in morphology induced anatomical alterations, such as increasing leaf thickness and diameter of stems. The effect of PBZ on the induction of morphological dan anatomical modification may be mediated by changing the plant hormonal balance.

The PBZ application with different concentrations resulted in different effects on the anatomical structure of the stems and leaves of Chrysanthemum varieties Jaguar Red, Snow White, and Fiji White. The length of the epidermal cells of Fiji White variety was higher than those of Snow White and Jaguar Red. Meanwhile, Jaguar Red produced greater stem thickness, number of stomata, and leaf thickness than those of the other two varieties. The concentration of $150 \mathrm{ppm}$ PBZ increased leaf thickness and stem diameter, as well as the tracheal diameter. The concentration of PBZ $100 \mathrm{ppm}$ increased the size of the guard cells, palisade, and spongy tissue, also peripheral tissues. While, the concentration of $50 \mathrm{ppm}$ PBZ increased the number of stomata and pith diameter. The optimum concentration of PBZ for potted Chrysanthemum was 150 ppm.

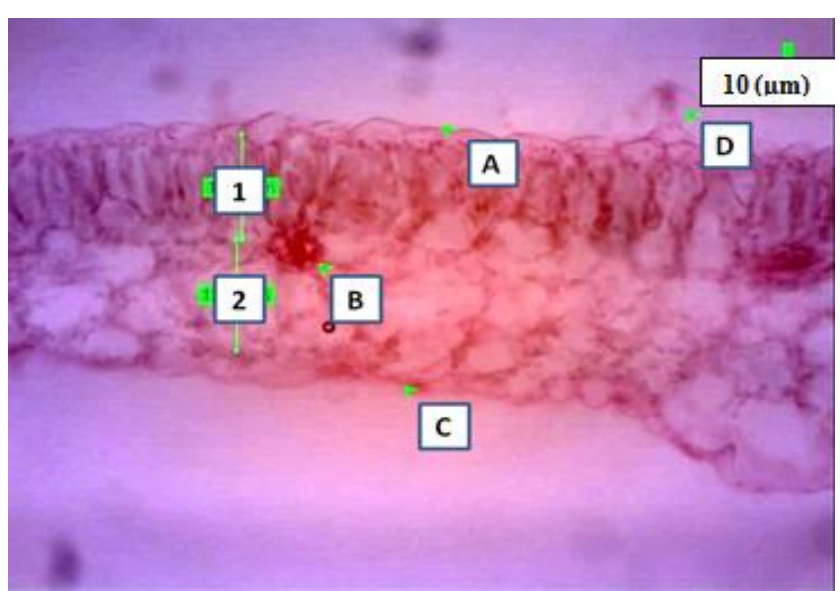

Figure 9. Cross-section of Chrysanthemum sp. leaves. A. Upper epidermis, B. Vascular bundle, C. Lower epidermis, D. Trichome. 1. Thickness of palisade tissue, 2. Thickness of spongy tissue

\section{ACKNOWLEDGEMENTS}

The authors express many thanks to Universitas Gadjah Mada for publication support under the Final Project Recognition Program (RTA 2020) Scheme. Many thanks are also given to Sudjino, Sutikno, Bambang Setyadi, and Prapti for many support during the research.

\section{REFERENCES}

Abd El-Aal MMM, Mohamed YFY. 2017. Effect of pinching and paclobutrazol on growth, flowering, anatomy and chemical compositions of potted geranium (Pelargonium zonal L.) plant. Intl J Plant Soil Sci 17 (6): 1-22.

Araujo AG, Val ADB, Soares JDR, Rodrigues FA, Pasqual M, Rocha HS, Asmar SA, Cordeiro ZJM, Silva SO. 2014. Host-pathogen interactions of Musa spp. and Mycosphaerella musicola with epidemiological variables and leaf anatomy within the pathosystem of Yellow Sigatoka disease. Aust J Crop Sci 8: 1200-1209.

Banerji BK, Datta SK. 2002. Induction and analysis of gamma rays induced flower head shape mutation in 'Lalima' Chrysanthemum (Chrysanthemum molifolium). Indian J Agric Sci 72 (1): 6-10.

Brailko VA, Mitrofanova OV, Smykova NV, Mitrofanova IV. 2018. Some morphological and physiological features of Chrysanthemum under in vitro culture. Acta Hortic 1201: 607-612.

Burrows GE, Boag TS, Stewart WP. 1992. Changes in leaf, stem, and root anatomy of Chrysanthemum cv. Lillian Hoek following paclobutrazol application. J. Plant Growth Regul 11: 189-194.

Dalaila I, Kusrinah, Lianah. 2019. Morfologi dan anatomi Chrysanthemum morifolium Ramat. var. puspita nusantara dan var. tirta ayuni serta Chrysanthemum indicum L.var. mustika kaniya. AlHayat J Biol Appl Biol 2 (2): 53-58.

Francescangeli N, Marinangeli P, Curvetto N. 2007. Paclobutrazol for height control of two Lilium L.A. hybrids grown in pots. Spanish J Agric Res 5 (3): 425-430.

Faust JE, Korcyznski PC, Klein R. 2001. Effects of paclobutrazol drench application date on Poinsettia height \& flowering. Hort Technol 11 (4): $557-559$.

Ferdinand J, Fredericksen T, Kouterick K, Skelly J. 2000. Leaf morphology and ozone sensitivity of two open-pollinated genotypes of black cherry (Prunus serotina) seedlings. Environ Pollut 108: 297302. 
Fuchs R, Kopischke M, Klapprodt C, Hause G, Meyer AJ, Schwarzlände M, Fricker MD, Lipka V. 2015. Immobilized subpopulations of lea epidermal mitochondria mediate PEN2-dependent pathogen entry control in Arabidopsis. Plant Cell 28: 130-145.

Gibson J, Gibson, Whipker BE. 2001. Ornamental cabbage \& kale growth responses to daminozide, paclobutrazol \& uniconazole. Hort Technol 11 (2): 226-229.

Haryanti S. 2010. Jumlah dan distribusi stomata pada daun beberapa spesies tanaman dikotil dan monokotil. Buletin Anatomi dan Fisiologi 18 (2): 21-28. [Indonesian]

Javelle M, Vernoud V, Rogowsky PM, Ingram GC. 2011. Epidermis: The formation and functions of a fundamental plant tissue. New Phytol 189: 17-39.

Mansuroglu S, Karaguzel O, Ortacesme V, Sayan MS. 2009. Effect of paclobutrazol on flowering, leaf and flower colour of Consolida orientalis. Pak J Bot 41 (5): 2323-2332.

Melotto M, Underwood W, He SY. 2008. Role of stomata in plant innate immunity and foliar bacterial diseases. Ann Rev Phytopathol 46: 101122.

Nazarudin MRA, Tsan FY, Normaniza O, Adzmi Y. 2015. Growth and anatomical responses in Xanthostemon chrysanthus as influenced by paclobutrazol and potassium nitrate. Sains Malays 44 (4): 483-489.

Nazarudin MRA, Tsan FY, Mohd Fauzi R. 2012. Morphological and physiological response of Syzygium myrtifolium (Roxb.) Walp. to paclobutrazol. Sains Malays 41 (10): 1187-1192.
Nazarudin MRA., Mohd Fauzi R, Tsan FY. 2007. Effects of paclobutrazol on the growth and anatomy of stems and leaves of Syzygium campanulatum. J Trop For Sci 19 (2): 86-91.

Puspitasari SA, Indradewa D. 2019. The effects of silica on growth and yield of Chrysanthemum plants (Dendranthema sp.) cultivar Sheena and Snow White. Ilmu Pertanian (Agricultural Science) 4 (3): 98-102. [Indonesian]

Rubiyanti N, Rochayat Y. 2015. Effect of paclobutrazol concentration and time of aplication to batik Rose. Jurnal Kultivasi 14 (1): 59-64. [Indonesian]

Ruzin SE. 1999. Plant Microtechnique \& Microscopy. Oxford University Press, New York

Soumya PR, Kumar P, Pal M. 2017. Paclobutrazol: A novel plant growth regulator and multi-stress ameliorant. Indian J Plant Physiol 22: 267278.

Tsegaw T, Hammes S, Robbertse J. 2005. Paclobutrazol-induced leaf, stem, and root anatomical modification in Potato. Hort Sci 40 (5): 1343-1346.

Wang Y, Zeng J, Xia X, Xu Y, Sun J, Gu J, Sun H, Lei H, Chen F, Jiang J, Fang W, Chen S. 2020. Comparative analysis of leaf trichomes, epidermal wax and defense enzymes activities in response to Puccinia horiana in Chrysanthemum and Ajania species. Hort Plant J 6 (3): 191-198.

Xu G, Liu Y, Chen S, Chen F. 2011. Potential structural and biochemical mechanisms of Compositae wild species resistance to Alternaria tenuissima. Russ J Plant Physiol 58: 491-497. 